\title{
The Implementation of Cooperative Learning Model Quiz-Quiz Trade and Inside-Outside Circle to Improve the Students' Communicative Skill and Learning on Social Science Lesson
}

\author{
Habidi $^{1)}$, Utami Widiati ${ }^{2)}$, Budi Eko Soetjipto ${ }^{3)}$ \\ Study Program of Basic Education, Graduate Program, Universitas Negeri Malang Indonesia
}

\begin{abstract}
The purpose of this study was to describe the implementation of cooperative learning model quizquiz trade and inside-outside circle in improving the students' communicative skills and learning outcomes on social science lessons. The subject is grade VIII junior high school Satu Atap Melai One Wakatobi in Academic Year 2016/2017 consisting of 20 students; 8 men and 12 women. The type of this research is Classroom Action Research. The data collection instrument consisted of the observation sheet activities of teachers and students, tests, interviews and documentation. This research was conducted in two cycles, each cycle consisting of four times. Each cycle consists of planning, implementing, collaborative observation, and reflection. The results of the study were. the percentage of implementation of cooperative learning model quiz-quiz trade and insideoutside circle was conducted by the teacher on cycle $1^{\text {st achieved }} 80.90 \%$ and in cycle $2^{\text {nd }}$ increased became $93.45 \%$ and students in cycle $1^{\text {st }}$ got $77.99 \%$ and cycle $2^{\text {nd }}$ became $14,42 \%$. The percentage of students communicate skills on cycle $1^{\text {st }}$ of $75.52 \%$ increased into $84.04 \%$ in cycle $2^{\text {nd }}$. The percentage of student learning outcomes in the cycle $1^{\text {st }}$ was $45 \%$ and it increased into $90 \%$ in cycle $2^{\text {nd }}$. The conclusions from the results of this research showed that through the implementation of cooperative learning model quiz-quiz trade and inside-outside circle could improve the implementation of the learning process of teachers and students as well as communicating skills could improve the students' learning outcomes on social science lessons in junior high school Satu Atap Melai One Wakatobi.
\end{abstract}

Keywords: $Q Q T, I O C$, CommunicativeSkills, Learning Outcomes

\section{INTRODUCTION}

Based on observation that was done by researchers of social science learning in junior high school Satu Atap Melai One Wakatobi on 18 March and 20 August 2016 found that there were some problems encountered in the learning process in the classroom so that it has not been appropriate on what was expected. The problems that havefound by the researcher were: 1) the teacher in the learning process of the social science in the classroom was still using conventional learning model that focused on teachercentre. The most dominant methods used were lecturing, asking questions, and giving assignments; 2) teachers in the learning process also dominated the talks while students were forced to sit, hear or record the subject matter delivered by the teacher; 3 ) in the process of social science learning in the classroom, the teacher was less creative in using learning models that exist, so the learning process that occurs only delivering the material; and 4) in the learning process of the social science in the classroom, the students were no courage, feeling of fear, rigid and erred in asking the question or opinion and answered the teacher's questions at the time of questioning or discussion group so that communication that happened was not the maximum.

In this case, it could negatively effect on the results of the study and students' communicative skills. The low results of students' learning and communicative skills in class VIII junior high school Satu Atap Melai One needed possible solutions and efforts. Because of this continues always happened so that the students were getting lazy to study social science lessons and feel boring. This condition caused social science learning process becoming unpleasant for the student as learners. Therefore, there should be an effort to make students feel happy and interested in social science lessons in the classroom, so hopefully it can improve the results of learning and students' communicative skills on social studies lessons.

The opportunityincommunicating has actually started in learning that was conducted by the teacher, it can be seen from the discussion and questioning that are often done in theclassroom. However, the expected communication skills haven't developed optimally. Communicative Skills are indispensable in the process of learning.In line with the statement from Dipalaya, Susilo, \& Corebima (2016:1714)communicative skills are indispensable to achieve the successfull in learning.According to Matin, Jandaghi, Karimi, \& Hamidizadeh (2010) States that communication is the process of exchange of messages from one person to another either by 
verbal or nonverbal. The student with the skills to communicate more easily communicate the variety of material pertaining to learning both spoken or written. According to DeVito (1997) there are five indicators of communicative skills, namely openness, empathy, supportiveness, positive attitude and equality. According Cvetic (2011) simplify and standardize the process of communication and the establishment of effective communication skills (such as clear verbal communication, concern on nonverbal communication and listening skills and conflict management) are steps to improve interaction and decrease or prevent communication. In the learning process, students should not only receive information, recall and memorization, but students are required to skilfully speak, skilled to ask questions, express opinions and ideas in front of a class or group discussions, actively engage and enrich themselves with ideas.

Based on the information found, low learning outcomes students are influenced by the interaction of the learning activity 1) interpersonal communication between students with students, students with teachers is low; 2) use of model of learning by teachers who are less precise and varied; 3) teachers are seen more often actively using conventional learning model. As a result of these circumstances make the students become passive and there was learning that centered on teacher (teacher centered), students are not given the opportunity to be involved in learning so that only acts as a listener only, as a result they are less sure about its ability to contend. Effective communication is not just about the exchange of information. Effective communication incorporating a set of capabilities such as nonverbal communication, listening intently, and the ability to carry themselves with a calm and confident in front of others(Reddy, Gopi, \& Aneel 2013:20).

According to Kagan \& Kagan (2009) a model of learning quiz-quiz trade hasfunctions such asclass building, social skills, knowledge building and learning procedure. While the learning model inside-outside circle hasfunctions such as class building, social skills, knowledge building and thinking skills that make up the student to actively communicate and cooperate so as to foster social skills.Cooperative Learning can be defined as a method of teaching that engages students in the learning process to understand and learn the contents of the subject (Slavin, 2011).Cooperative Learning is composed of five basic elements: positive addiction, the promotion of interaction, individual accountability of teaching social and interpersonal skills, and quality of processing group(Tran 2014:131).

According toKagan\&High (2002) described cooperative learning as a teaching method in which students work in groups and interaction in it to guarantee the positive freedom, individual accountability, equal participation, and interaction at the same time. Model learning of quiz-quiz trade is a model of cooperative learning that is carried out by two students, they are paired and Exchange questions using the card, the card inside the teachers have prepared questions. In practice, teacher divides the students into two groups, once divided and met her partner they are answering questions and explaining that already exist in the card so on until time has been determined.

While the cooperative learning model in inside-outside circlelearning is a model system with inside circle and outside circle. In practice, teacher divides a half of the existing number of students into two groups and form an inside circle facing out and the rest forms the outside circle facing into inside. Here, students face each other and share information simultaneously with the card that is already provided by the teacher, students who were in the inside circle rotates clockwise then share information to front side of new friends, and so on until the time has been determined. This can be a good strategy to find out students' understanding, review process, the practice of dialogue in the book text, and a meeting with classmates(Liang 2002:36).

The existence of cooperative learning model quiz-quiz trade and inside-outside circle, existing problems in the classroom can be completed, in addition to working students, contribute together, and skilled in communicating or delivering an opinion, theideas and the idea ofa very helpful once in their everyday lives, so in the process of learning can run as expected.More interesting Results gotten showed that students' success through cooperativelearning relate to their satisfaction in the activity, perception, a feeling of success in learning, a learning experience, and the level of activity (Uhler\& Lanter2012). Cooperative learning is an effective method to use in problem-solving task due to encourage students to express their views (Leasa \& Corebima 2017).

According to Afian (2011:217)excellencefromthe learning modelquiz-quiz tradeis this model emphasize to students how to exchange information, build knowledge and teach something to others, so that students are more expected to absorb the material.Communicative skills are highly popularized in this model(Soetjipto2010:189). The students who are less ably convey material trained through this model. While according to Ningtiyanti (2016:25) stated that the excellence of learning methods inside-outside circle is the existence of a clear structure andallow students to share with a different partner in short and regular. In addition tothat, the students work with fellow students in an atmosphere of cooperative and have manyopportunities to cultivate and improve the skills of communicative information.In an attempt to overcome these problems, need solutions to solve problems by applying cooperative learning model quiz-quiz trade and inside-outside circle. Cooperative learning model quiz-quiz trade and inside-outside circle is a learning model developed by Kagan \& Kagan. The main strength of the cooperative education as a practice-based learning strategy lies not in how 
students gain the opportunity to learn in the classroom and in the workplace, but this opportunity be integrated to form a better learning of the these parts(Eames \& Coll 2010).According to Davoudi \& Mahimpo (2012:1139) declared that the teacher can learn some simple structures so that it becomes more confident through the implementation of cooperative learning. The ability of the students grow where they can demonstrate the ideas, concerns, and feelings. Cooperative learning model Kagan allows learners learn better due to Language learning environment is not boring. The researchers used a model cooperative learning quiz-quiz trade and inside-outside circleit because it is very suitable to be applied in Junior High School Satu Atap Melai One so that the process of learning in that school can improve learning outcomes and students' communicative skill. Students can also actively study and cultivate social skills and can improve the ability to communicate between fellow processed so that it can improve student learning outcomes. The structure of cooperative learning more authentic, representative, and judgment is more efficient (Kagan, 2009: 15.6).

Therefore, the researchers conducted a classroom action research (CAR) and choose to implement cooperative learning model quiz quiz-trade and the inside-outside circle that can improve communication skills and student learning outcomes in class VIII junior high school the country one roof Melai One Wakatobi.

\section{METHOD}

The type of this research is Classroom Action Research (CAR).It is a process of Research studies on learning in the classroom through self-reflection in efforts to solve the problem with how to do a variety of actions planned in real situation and analyze the influence in each treatment (Sanjaya, 2015:44). Research in CAR was done by two cycles, each consisting of four phases, namely planning, implementation, observation, and reflection. The subject in this study was grade VIII Junior High School Satu Atap Melai One that consisted of 20 students; 8 men and 12 women. The time of the research was carried out in January and February 2017.

The instruments of this research were observation sheet of the implementation of the learning process by teachers and students. Instrument of students' communicative skills using observation sheet assessment of several aspects; openness, empathy, being supportive, positive attitude, and equality. The student learning outcomes was used the cognitive test.

\subsection{Learning Implementation}

\section{RESULTS}

Implementation of the learning gained from the learning process observation sheets filled out by the observer. The data analysis done by dividing the score obtained by the maximum score is then multiplied by $100 \%$. Following the results of the data analysis exercise of learning can be seen in table 1 .

Table 1. Results Lesson by Teacher and Student

\begin{tabular}{|l|l|c|c|c|c|}
\hline No. & \multicolumn{1}{|c|}{ Observation } & Cycle 1 $^{\text {st }}$ & Cycle 2 $^{\text {nd }}$ & $\begin{array}{c}\text { Improveme } \\
\text { nt }\end{array}$ & Criteria \\
\hline 1. & Implementation of learning by teachers & $80.09 \%$ & $93.45 \%$ & $13.36 \%$ & very good \\
2. & Implementation oflearning bystudents & $77.99 \%$ & $92.41 \%$ & $14.42 \%$ & very good \\
\hline
\end{tabular}

Based on Table 1 it can be stated that implementation of the learning experience increased with the criteria very well. The graph of the increased implementation of learning can be seen in Figure 1 .

\section{Figure 1. Enhanced Learning Implementation by Teachers and Students}

\subsection{The students' Communicative Skill}

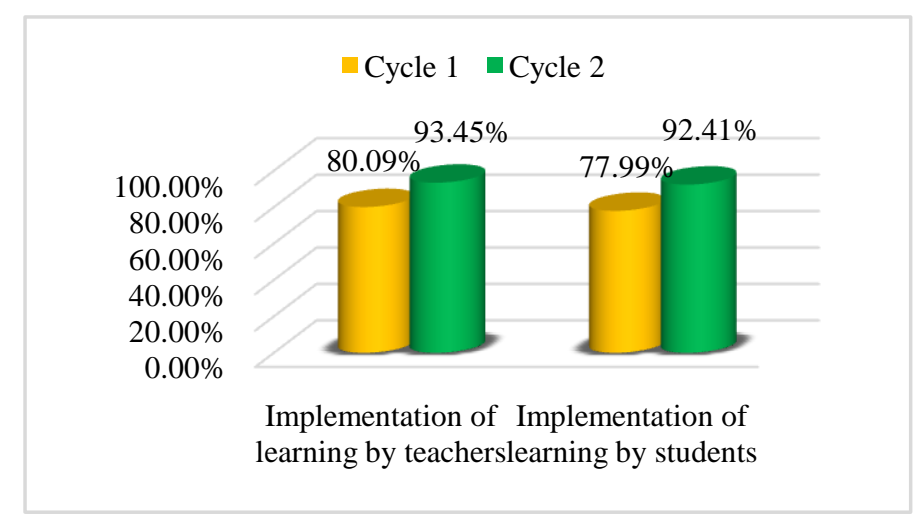

The students' communicative skills were measured based on the result of observation that conducted 
by the observer in each meeting on the cycle $1^{\text {st }}$ and cycle $2^{\text {nd }}$. The data analysis was done by dividing the score obtained by the maximum score was then multiplied by $100 \%$. The results of the analysis of the median then flatten. The following is the results of student's communicative skills. It can be seen in table 2 :

Table 2. Results of Students' Communicative Skills

\begin{tabular}{|c|l|c|c|c|c|}
\hline No. & $\begin{array}{c}\text { Aspects of } \\
\text { Assessment }\end{array}$ & Cycle 1 $^{\text {st }}$ & Cycle 2 $^{\text {nd }}$ & Improvement & Criteria \\
\hline 1. & Openness & $85.21 \%$ & $92.08 \%$ & $6.87 \%$ & Very Good \\
2. & Empathy & $73.96 \%$ & $8521 \%$ & $11.25 \%$ & Very Good \\
3. & Support Attitude & $60.00 \%$ & $75.94 \%$ & $15.94 \%$ & Good \\
4. & Positive Attitude & $74.38 \%$ & $78.85 \%$ & $4.47 \%$ & Good \\
5. & Equality & $84.06 \%$ & $88.13 \%$ & $4.07 \%$ & Very Good \\
\hline & average & $75.52 \%$ & $84.04 \%$ & $8.52 \%$ & Very Good \\
\hline
\end{tabular}

Based on table 2 results, it can be knownthat the students' communicative skills have increased. The graph of the students 'communicative skill results can be seen in Figure 2.

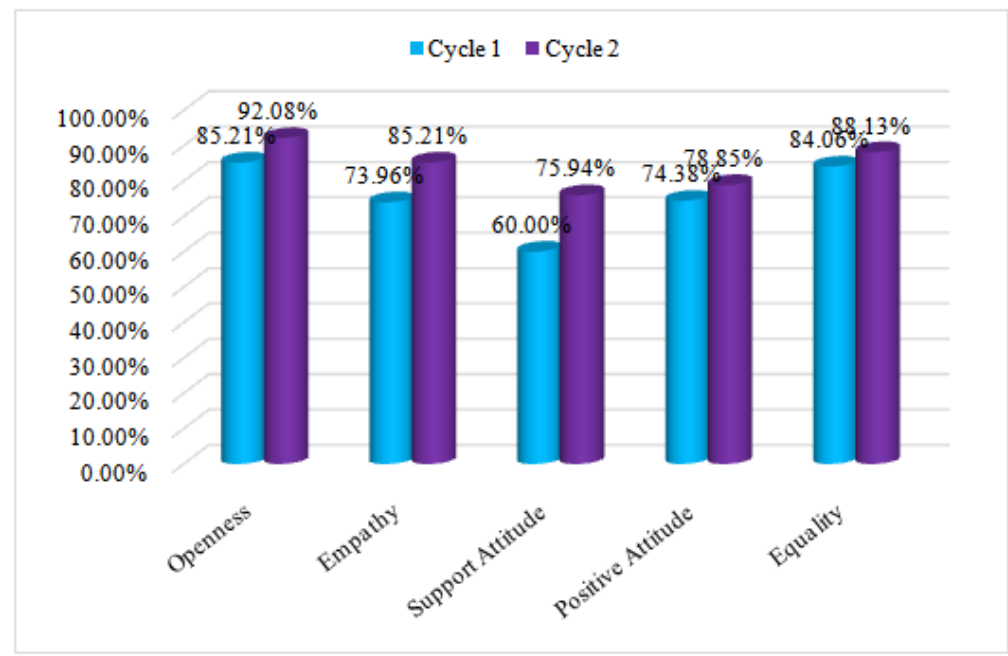

Figure 2. The Results of Students' Communicative Skills

\subsection{Students' Learning Outcomes}

The data were assessed on cognitive learning obtained from the post-testin the end of each cycle $1^{\text {st }}$ and cycle $2^{\text {nd }}$. The classical learning completeness of the students is calculated by dividing the number of students who completed with the total number of students and it is then multiplied by $100 \%$. The data of the students' learning outcomes improvement from the first cycle to the second cycle can be seen in Table 3 .

Table 3. Results of Student

\begin{tabular}{|c|c|c|c|c|c|c|c|c|}
\hline \multirow[t]{2}{*}{ No. } & \multirow{2}{*}{$\begin{array}{l}\text { Value } \\
\text { Range }\end{array}$} & \multicolumn{2}{|c|}{ Cycle $1^{\text {st }}$} & \multicolumn{2}{|c|}{ Cycle $2^{\text {nd }}$} & \multicolumn{2}{|c|}{ Improved } & \multirow{2}{*}{$\begin{array}{c}\text { Descriptio } \\
\text { n }\end{array}$} \\
\hline & & $\square$ & $\begin{array}{c}\text { Student } \\
\%\end{array}$ & $\square$ & $\begin{array}{c}\text { Student } \\
\%\end{array}$ & $\begin{array}{c}\square \\
\text { Student } \\
\text { s }\end{array}$ & $\begin{array}{c}100 \\
\%\end{array}$ & \\
\hline 1 & 70 to 100 & 9 & $45 \%$ & 18 & $90 \%$ & 9 & $45 \%$ & Completed \\
\hline 2. & $<70$ & 11 & $55 \%$ & 2 & $10 \%$ & & & $\begin{array}{c}\text { Not } \\
\text { Completed }\end{array}$ \\
\hline & Total & & $\begin{array}{c}20 \\
100 \%\end{array}$ & 20 & $100 \%$ & & & \\
\hline
\end{tabular}

Based on Table 3, it can be seen the improvement of the students' learning outcomes. The graph of students' learning outcomes can be seen in Figure 3. 
Figure 3.Student Learning Outcomes

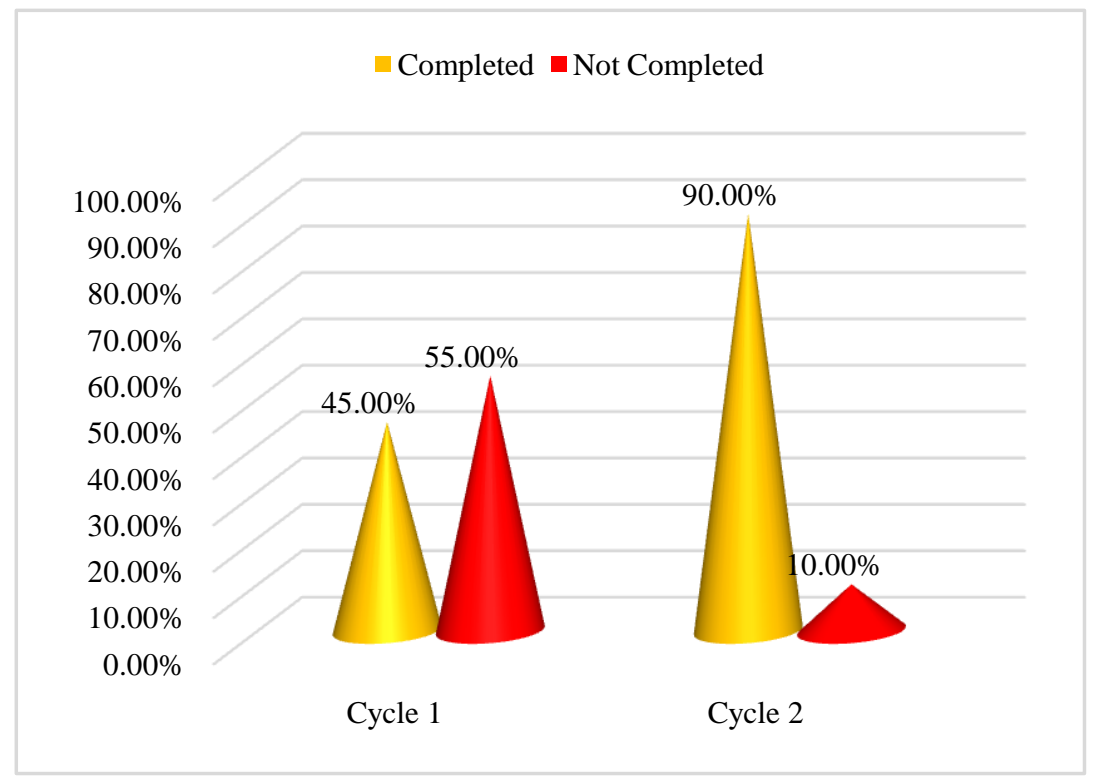

\section{DISCUSSION}

\subsection{Implementation of Learning by Teacher and Student}

Learning model quiz-quiz trade and inside-outside circle is a cooperative learning model developed by Kagan \& Kagan. It is like the other models of cooperative learning; model of learning quiz-quiz trade and inside-outside circle is a group learning in pairs and form a circle using the reserved answers card. In the implementation of both the cooperative learning involves the active students in learning, so that may give rise to an attitude of social skills, improved interpersonal skills, leading to a sense of cohesiveness within the interact so as to establish cooperation in exchanging information between fellow students.

According to Soetjipto (2010:201) modellearningquiz-quiz trade can emphasizes to students to How to exchange information, build knowledge and teach something to others, so the studentsare expected to be more absorbing material". While according to Suyatno (2009:69) "model of learninginside-outside circle learning is a model system with a small circle and big circle where students sharing information at the same time with a different partner with short and regular. In the implementation of model learning quiz-quiz trade andinsideoutside circlein Junior High School Satu Atap Melai One, the researcher divided the students into two groups; there were Group A (top) and Group B (down) on the basis ofthe students 'academic ability.

The implementation of cooperative learning model quiz-quiz trade and inside-outside circle in Junior High School Satu Atap Melai One was done in two cycles in which each cycle consisted of four times. The application of model learning quiz-quiz trade was held on the first and third meetings while learning model inside-outside circle meetings were held on the second and fourth. In the implementation of the process of learning is to know the accuracy of the application of the cooperative learning model quiz-quiz trade and insideoutside circle used observation sheets of accuracy and the execution of the learning process by teachers and students. They were observed by two teachers' observer.

On the application of cooperative learning model quiz-quiz trade and inside-outside circle incycle $1^{\text {st }}$, there still had many weakness due to on the application of cooperative learning model quiz-quiz trade-in the first and third meetings, students were still shy and hesitant when asked his partner to use the card, students always forgot to raise their hand when finished asking his/her partner. Whereas, the application of the cooperative learning model in inside-outside circle in the second and fourth meetings, the students always made joking around and playing, students at a time when rotating clockwise was still always find the same spouse, the teacher made trouble in setting the time at the time of implementation of the activities of the learning process as planned in the implementation of the learning. This led to the results of the implementation of the process of learning quiz-quiz trade and inside-outside circle have not yet reached the success because under $81 \%$ i.e. Out of $80.09 \%$ for the implementation of learning by teachers and of $77.99 \%$ for the implementation of the process of learning by students.

After conducting the reflections and the improvements in cycle $2^{\text {nd }}$, it obtained an increase in the implementation of the process learning by teachers namely of $93.45 \%$ was categorized excellent and $92.41 \%$ on the implementation process of learning by students was also categorized excellent. In line with the results of the study of Wahyu (2015) stated that these problems can be overcome on the cycle $2^{\text {nd }}$ so that learning can 
runsmoothly and as planned. The improvement that was done on this cycle $2^{\text {nd }}$ were the teacher in the learning process has been successful in implementing and it was appropriate with the time that was provided lesson plans, students become accustomed and not shy or hesitant in performing the activities of cooperative learning quiz-quiz trade if they raised their hand after the completing asking and answering on her partner, the next model in inside-outside circle of students did not make joking around and playing in answering the question of his running mate so that students could be serious and confident in their group. The students could interact with her partner, shared information and gave praise against his/her friends so that it could improve social skills. The studentworked based on the teacher's instruction to fit spinning clockwise that had found the right partner. The students who worked in groups were very cooperative, helping one another to do better during class activities (Gull \& Hashim 2015:252). The main activity of cooperative learning was the students who worked in a group, try to hit the target together, thus it could add the value to the Group's success. This component helped the students in many other ways, for example, in improving themselves conceptual, self-confidence (Zakaria, Solfotri, David, \& Abidin 2013:100), clearing of social skills and class participation was increasing. The teacher as educators provided thestudents with attention to how to motivate, educate so that learning was done running optimally. The results of the research conducted by Khakiim, Degeng \& Widiati (2016:1732) stated that teacher did motivation by showing warmth and enthusiastic when communicating and interacting with the students.

\subsection{The Students' Communicative Skill}

In observation sheet of students' communicative skill, there are 5 aspects of the assessment that being observed, namely: 1) openness, include: students can start any new relationship with others, students can demonstrate openness in relationships with others, and students can show their self-confidence to others and share the feeling with a greeting or be shaken; 2) empathy, include: students can demonstrate the attention to others when speaking, students can keep the feelings of others at the moment of speaking, and the students can understand the desires of others while receiving the questions or the answers during speaking; 3) supportiveness, include: students can give an explanation if it is not able to answer the question correctly, students can give an award/commendation against talking after answering a question correctly, and the students do activities in spontaneity while talking with friends; 4) positiveness, include: the students can appreciate the difference of opinions to others when asking and answering questions, students can think positively towards others while talking, and unsuspecting students excessively against the talking; and 5) equality, students can recognize the importance of the presence of others addressed by not feeling shy, nervous and jittery at a time when speaking, students do not dominate talks when communicating with others, and students can communicate with the familiar and comfortable with the caller.

The results of the observation of students' communicative skill that was done by two observers, on cycle $1^{\text {st }}$ obtained an average percentage $75.52 \%$ with good criteria. While on cycle $2^{\text {nd }}$ gained a percentage of the average value of $84.04 \%$ with the criteria very well. Based on the analysis above, it can be said that the application of the cooperative learning model quiz-quiz trade and inside-outside circle could improve the students' communicative skills. It is well known that students do not feel awkward and hesitant in delivering answers to his/her partner, students already feel convinced and confident over on the ability to communicate between fellow using the card. In addition to that, students can work together in delivering a message or search for information, as well as actively involved in learning so that it can improve the students' ability in communication. The research that was conducted Riyadi, Soetjipto \& Amiruddin (2016:94) stated that students in his group seeks to link concepts that have been owned and developed the concept in depth through group discussion activities, students are able to communicate information with a good, complete their duties with full responsibility, students help each other to solve problems and share the material with his friends, students work together in earnest, no longer be passive in the classroom, every issue completed in groups by means of expression respectively. The research that was conducted by Dewi (2016) in cycle $1^{\text {st }}$, the students' communicative skill with a learning model of application of Two Stay Two Strayand Round Robin retrieved $74.03 \%$ and has increased significantly on the cycle $2^{\text {nd }}$ of $81.34 \%$ so that it can be concluded that learning through the application of TSTS and Round Robin can improve students' communicative skills and learning outcomes of Social Science in SDN Kupang 1 Jabongrade IV.

\subsection{The Students' Learning Outcomes}

The student learning outcomes measured in this study is the result of student learning in the cognitive domain with levels C1, C2 and C3 that are made by researcher refers to the book of curriculum 2013 grade VIII in semester 2. This book is taken from the Ministry of education and culture. The instrument of the students' learning outcomes tests is created by researchers in the form of the written tests are multiple choice and descriptions that consists of 25 items. As for the terms of the minimum passing grade (MPG), students with a value of 70. The improvement of students' learning outcomes can be seen from the development of the results of the students' test scores at the end of each cycle. 
In $1^{\text {st }}$ cycle, there were 9 students who achieved MPG, whereas students who had yet to achieve MPG Consisted of 11 students. Seeing from the results of students' learning success at the $1^{\text {st }}$ cycle, there were the students who had not succeeded because the students were still completely under MPG. But if comparing with result of the learning in the pre-test the number of students who completed MGP increased $45 \%$ in $1^{\text {st }}$ cycle.

In $2^{\text {nd }} \mathrm{Cycle}$, it has been completed the results of students who achieved in which 18 students or by $90 \%$, while the value that had not reached MGP consisted of 2 students. Seeing the result of the students' learning outcome has been achieved the criteria of success in $2^{\text {nd }}$ cycle. Thus, the results of the students' achievement from $1^{\text {st }}$ cycle to $2^{\text {nd }}$ cycle has increased. Based on the analysis results, it can be stated that with the application of learning model cooperative quiz-quiz trade and inside-outside circle could improve the students' learning outcomes in social science class VIII in Junior High School Satu Atap Melai One Wakatobi.

The successfulness of the students' learning outcomes was caused the students enthusiastically learn and colonized subject matter by using model quiz-quiz trade and inside-outside circle that occurred on $2^{\text {nd }}$ cycle so there was an improvement on in. The students also showed good achievements in social science lessons after the teacher giving tests. During the implementation of the actions, the teachers provided the motivation, direction, and guidance during the learning process took place so that students got good grades. The effort of the students to get good grades was in earnest and diligent to study so that a predetermined learning objectives could be achieved. In line with research conducted by Nurhaniyah, Soetjipto \& Hanurawan (2015:168) explained that the students wanted to get good grades because they wanted to be more proficient in the subject of social science, and considered that social science was useful to their lives. The reason students above indicated a strong desire to be the best. To realize the achievement of required capabilities in the mastery of the subject matter. The efforts made by students to get good grades was diligently in learning, trying and praying. The attitude and effort students above ought to be appreciated that they already had a concern to keep learning.

\section{CONCLUSSIONS AND RECOMMENDATION}

Based on the results of the study it can be concluded that the application of the cooperative learning model quiz-quiz trade and inside-outside circle could enhance the learning process of teachers and students in the social sciences lesson, especially at the implementation $2^{\text {nd }}$ cycle, implementation of learning by teachers increased from $80.09 \%$ in $1^{\text {st }}$ cycle became the $93.45 \%$ in $2^{\text {nd }}$ cycle, implementation of learning by students increased from $77.99 \%$ in $1^{\text {st }}$ cycle became the $92.41 \%$ in $2^{\text {nd }}$ cycle. Besides, the students' communicative skill also increased from $1^{\text {st }}$ cycle to $2^{\text {nd }}$ cycle in which of $84,04 \%$, and the results of student learning increased by $90 \%$. Based on the results of the study, it is suggested to use the various models and learning media in any process of learning activities that can help teachers and students in learning. In addition to that, the learning objectives should be achieved at each meeting properly. Therefore, it is expected to every teacher particularly the teacher of social science can apply the learning models that he/she knew and it is developed in any activity the learning process. It is aimed to make the students do not feel bored and saturated in learning. The Social Science Teachers' Forum are expected to always conduct the meeting in any activity so that they can add their insight and knowledge about a wide variety of learning models that exist. In order to be developed and applied in school, techniques or learning strategies should be mastered by the teacher in order they can develop their creativity and professionalism.

\section{REFERENCES}

[1] Afian, A. 2011. Penerapan Pembelajaran Kooperatif Kolaboratif Model Quiz-Quiz Trade dan Team Games Tournament untuk Meningkatkan Hasil Belajar, Keaktifan Belajar dan Selft Esteem (Studi Pada Mahasiswa Universitas Kanjuruhan Malang Semester Genap 2010-2011)Unpublished Thesis: State University of Malang.

[2] Davoudi, M.H.A. \& Mahimpo, B. 2012. Kagan Cooperative Learning Model: The Bridge to Foreign Language Learning in the ThirdMillennium's 1799-2591 Theory and Practice in Language Studies, Vol. 2, No. 6, pp. 1134-1140, June 2012. Manufactured Publisher Academy in Finland. (Online). https://scholar.google.co.id/.Accessed on November 22, 2016.

[3] DeVito, J. 1997. Communication Between Humans. Translated by Agus Maulana. Jakarta: Professional Book.

[4] Dewi, F.D.R. 2016. Application of Learning Model TSTS and Round Robin to Improve Communication Skills and Learning Outcomes IPS Grade IV SDNKupang 1 Jabon.Unpublished thesis. Malang: The Malang State University.

[5] Dipalaya, T., Susilo, H. \& Corebima, A.D. 2016. Influence of Learning Strategies Pdeode (PredictDiscuss-Observe-Explain-Discuss-Explain) on Academic Ability Didderently to Communication Skills of Students. Different. Biology Graduate-University of Malang. Journal of Education: Theory, Research, and Development Volume: 1 Number: 9 Months September 2016 Pages: 1713-1720. EISSN: 2502-471X. https://scholar.google.co.id/.Accessed on March 12, 2016. 
[6] Eames, C. \& Coll, R.K. 2010. Cooperative Education: Integrating Classroom and WorkplaceLearning. University of Waikato, New Zealand. Pages pp 180-196. DOI 10.1007 / 978-90-481-3939-2_10 Online ISBN 978-90-481-3939-2. Publisher Springer Netherlands Date: 20 April 2010.https://link.springer.com/chapter/10.1007/978-90-481-3939-2_10https://scholar.google.co.id/

[7] Gull. F., \&Shehzad, S. 2015.Effects of Cooperative Learning on Students' AcademicAchievement.University of the Punjab, Lahore, Pakistan. Journal of Education and Learning. Vol. 9 (3) pp. 246-255. (Online). https://scholar.google.co.id/.Accessed on November 22, 2016.

[8] Kagan, S., \& High, J. 2002. Kagan Structures for English Language Learners.ESL Magazine. Retrieved from. http://www.kaganonline.com/free_articles/dr_spencer_kagan/356/ESL-Magazine-KaganStructures-for-English-Language-Learners

[9] Kagan, S. \& Kagan, M. 2009. Kagan cooperativelearning.San Clemente: Kagan Publishing.

[10] Khakiim, U. Degeng, S.N. \& Widiati, U. 2016. Pelaksanaan Membuka dan Menutup Pelajaran Oleh Guru Kelas 1 Sekolah Dasar. Jurnal Pendidikan: Teori, Penelitian, dan Pengembangan Volume: 1 Nomor: 9 Bulan September Tahun 2016. Pendidikan Dasar Pascasarjana Universitas Negeri Malang. (Online). https://scholar.google.co.id/. Accessed on March 12, 2017.

[11] Liang, T. 2002. Implementing Cooperative Learning in EFL Teaching: Process andEffects. https://scholar.google.co.id/ www.asian-efl-journal.com

[12] Leasa, M. \& Corebima, A.D. 2017. The effect of numbered heads together (NHT) cooperative learning model on the cognitive achievement of students with different academic ability. Faculty of Teachers Training and Education, Pattimura University. Journal of Physics: Conf. Series 795 (2017) 012071 doi:10.1088/1742-6596/795/1/012071 IP Address: 180.247.146.204. Journal of Physics: Conference Series, Volume 795, conference 1. http://iopscience.iop.org/article. https://scholar.google.co.id/.

[13] Matin, H.Z., Jandaghi, G., Karimi, F.H., \& Hamidizadeh, A. 2010. Relationship between Interpersonal Communication Skills and Organizational Commitment (Case Study: Jahad Keshavarzi and University of Qom, Iran). University of Tehran, Iran. European Journal of Social Sciences. Volume 13, Number 3 (2010). ejournal.narotama.ac.id/files/ejss_13_3_06. https://scholar.google.co.id/

[14] Ningtiyanti, U.S. 2016. Upaya Meningkatkan Kemampuan Mengenal Cerita Diri Melalui Metode IOC (Inside Outside Circle). Jurnal Penelitian Pendidikan Indonesia (JPPI). Vol. 1, No. 1, Januari 2016. (Online), http://i-rpp.com/index.php/jpp/article/view/357.Accessed on June 2, 2016.

[15] Nurhaniyah, B., Soetjipto., B.E., \& Hanurawan, F. 2015. The Implementation of Collaborative Learning Model Find Someone Who and Flashcard Game to Enhance Social Studies Learning Motivation for the Fifth Grade. Students. Journal of Education and Practice. ISSN 2222-288X.Vol. 6, No. 17, 2015. (Online) https://eric.ed.gov/?id=EJ1079791. Accessed March on 12, 2017.

[16] Reddy, B.B., Gopi, M.M., \& Aneel, Y. 2013. Having Effective Communication Skills are Indispensable for the Successful Career of EngineeringStudents. Department of B \& HS, Siddharth Institute of Engineering \& Technology, Narayanavanam Road, Puttur-517 583, Chittoor (Dist), AP (State), INDIA. IOSR Journal of Humanities and Social Science (IOSR-JHSS) Volume 11, Issue 4 (May. - Apr. 2013), PP 20-22 e-ISSN: 2279-0837, p-ISSN: 2279-0845. www.Iosrjournals.Orghttps://scholar.google.co.id/

[17] Riyadi, A., Soetjipto, B.E., \& Amirudin, A. 2016. The Implementation of Cooperative Learning Model Fan-N-Pick and Quick on the Draw to Enhance Social Competence and Cognitive Learning outcome for SocialStudies.IOSR Journal of Humanities and Social Science (IOSR-JHSS) Volume 21, Issue 4, Ver. I (Apr. 2016) PP 90-96 e-ISSN: 2279-0837, p-ISSN: 2279-0845. (Online) www.iosrjournals.org/iosrjhss/papers/.../L2104019096.Accessed March 12, 2017.

[18] Sanjaya, W. 2015. Penelitian Tindakan Kelas.Jakarta: Prenamedia Group.

[19] Suyatno. 2009. Menjelajah Pembelajaran Inovatif. Sidoarjo: Masmedia Buana Pustaka.

[20] Soetjipto, B.E. 2010. Pembelajaran Kooperatif dan Beberapa Hasil Penelitian Bidang Manajemen dan Ekonomi. Malang: Universitas Negeri Malang.

[21] Slavin, R.E. 2011. Instruction Based on Cooperative Learning. In R.E. Mayer \& P.A. Alexander (Eds.), Handbook of Research on Learning and Instruction (pp. 344-360). New York: Taylor \& Francis.

[22] Uhler,B.E.\&Lanter,J.R. 2012. Perceptions of Group-Led Online Discussions: The Benefits of CooperativeLearning.Miami University, Ohio. Kutztown University, Pennsylvania. First Published August 30, 2012 research-article. Volume: 40 issue: 4 page (s): 381388.DOI:http://journals.sagepub.com/doi/abs/10.2190/ET.40.4.d. https://scholar.google.co.id/abstract

[23] Tran, V.D. 2014. The Effects of Cooperative Learning on the Academic Achievement and KnowledgeRetention. Faculty of Education, An Giang University, Vietnam, An Giang, Vietnam. Vol. 3, No. 2; 2014. International Journal of Higher Education. Published Online: May 6, 2014 doi: 10.5430 / ijhe. v3n2p131. URL: http://dx.doi.org/10.5430/ijhe.v3n2p131. www.sciedu.ca/ijhe.(Online). https://scholar.google.co.id/.Accessed November 22, 2016. 
[24] Revelation, M. 2015. Collaboration Cooperative Learning Quiz-Quiz Trade and Fan N Pick to Improve Motivation and Learning Outcomes IPS (Studies in Class VIII SMP Negeri 3 Bati-Bati TanahLaut).Unpublished thesis. Malang: The Malang State University.

[25] Wahyu, M. 2015. Kolaborasi Pembelajaran Kooperatif Tipe Quiz-Quiz Trade dan Fan N Pick untuk Meningkatkan Motivasi dan Hasil Belajar IPS (Studi di Kelas VIII SMP Negeri 3 Bati-Bati Kabupaten Tanah Laut). Unpublished Thesis: State University of Malang.

[26] Zakaria, E., Solffitri, T., David, Y., Abidin, Z.Z. 2013. Effect of Cooperative Learning on Secondary School Students' Mathematic achievement. Creative education, 4 (2), 98-100. Retrieved from: http://www.scir.org/journal/ce; http://dx.doi.org/10.4236/ce.213.42014. May 10th2014. (Online). https://scholar.google.co.id/. Accessed on March 12, 2017. 